\title{
correspondence
}

\section{Researchers and the SRC}

Sir,- - We are a group of non-tenured research faculty who have been working for the University of Sussex for periods up to and exceeding ten years, during which time the university has benefited both from our skills and reputation and from the capital funds attracted by our research.

We have read with interest the recent articles in Nature which discussed the problems of people in our situation and would like readers to be aware of our existence as a group and of our position on the issues. We feel that the problem-while certainly a national problem-can, in fact, be solved by local action at university level: the issue is not one concerning redundancy payments, but that the university can, and should, provide permanent tenured employment for those of us who have demonstrated our proficiency and usefulness in the past.

The discussion in Nature has so far been concerned with researchers who derived their support from the MRC but there are many who have been supported for long periods by the Science Research Council. The SRC seems to support fundamental research in this country on the hypocritical assumption that it is the universities and their tenured staff who are carrying out the research. In fact, because of the increasing complexity of research projects and the increasing demands on the time of tenured faculty, it seems that no university group can perform any really ground-breaking research without the help of some full-time, post-doctoral research personnel. Under present conditions these research personnel are almost always non-tenured. In spite of the essential role played by these non-tenured researchers in doing the actual research the SRC maintains a policy of not supporting non-tenured research workers beyond a certain age.

In the past there was enough turnover in university and national laboratory personnel so that most non-tenured research workers eventually found a post. Also, the University Grants Committee used to provide funds to allow research projects to be "taken over" by universities but this no longer occurs. Many SRC officials, and perhaps the Council itself, still seem to feel that the universities are under an obligation to give permanent employment to research workers even though the universities claim this is impossible to do.

Even when they are in a position to make appointments the universities are not living up to their responsibilities. The majority of recent new university posts have been limited to the first few points on the lecturer's scale, thereby restricting them to people about thirty or vounger. One of us was told by a professor who had just made an appointment, that he did not think any universitv would ever offer him a lectureship because of his seniorityreferring both to his age and abilities.
On a less personal level, the university here has refused to give any undertaking, in negotiations with the AUT, to show some preference to older people in temporary positions when and if new posts become available.

It is clear that in many cases the $\mathrm{SRC}$ is aware of the current situation. One of our members is currently supported under a research grant which contains a special condition that requires the university to employ only that particular individual as the researcher on that project, thus explicitly recognising his essential role. The SRC must however face the fact that at the moment scientific research in this country is conducted on an unconscionable basis, with untenured research personnel being treated like serfs in a feudal society, rather than the workers providing the intellectual capital which is essential to the future of a society which prides itself on its democratic traditions. The present organisation of research is basically inefficient and unstable and cannot be continued much longer: the conditions of employment of non-tenured research workers would not be tolerated in any other sector of our society.

Present SRC policies include: age restrictions on appointments to SRC establishments; age restrictions on the non-tenured research personnel supported by SRC grants; attempts to force the universities to "take over" rescarch contracts and personnel while the UGC refuses to provide the resources for such "take overs"; and restriction of the right to apply for SRC research grants to tenured members of university faculties. These are making an already difficult situation incalculably more damaging than it has to be.

There is evidently a need for basic research if Britain is to maintain any sort of competitive position in the developed world. The only way we can compete in international markets is by making maximum use of the skills and creative abilities of our people not by discarding those of us who have mastered and perfected some of the most sophisticated skills necessary for complex modern technologies.

R. Golub, G. Nfwton, M. Giles

University of Sussex, $U K$

\section{Seismic prediction at Pozzuoli}

Sir,-Tazieff ( 8 September 1977, page 96) makes accusations that I

deliberately put about wrong data in 1970 concerning warning signs that an erruption could occur in the vicinity of the city of Pozzuoli. This is not the first time he has made this statement and I have already answered him in a technical note presented to the Pontanian Academy in 1973, a copy of which I sent to him. I can state that it is completely untrue that I was the source of bulletins or news of an impending eruption in Campi Flegrei.

Indeed to the best of my knowledge no such news was spread at all

Perhaps I may go further. Tazieff speaks of false claims of a "conspicuous temperature rise of the Solfatara's fumaroles"; but in 1970 I wrote "geothermal measurements at the Solfatara have not shown up to June 9 (the date I corrected proofs), any, sensible variation in temperature". Tazicff further speaks of false claims of extremely shallow earthquakes, claiming his team disproved their existence. A paper by I. Guerra et al. in Ouaderni della Ricerca Scientifica No. 82 (1972) reproduces the seismograms from these quakes and mentions a "superficiality of foci". Finally Tazieff says that the vertical ground movement or brady-seism was no faster than usually noticed over the centuries as opposed to claims that the ground had been pushed up one metre in a "very short while". Readers can judge for themselves by looking at Casertano et al. (Nature 264, 161-164;

1976) whether the motion was average in my reckoning it went up to $60-70$ times average.

During my involvement in these matters I acted according to my mora duties without any external pressure. Only after the order to move out of tottering houses (not the city, as Tazicff declares) could I rest peacefully, and even then of course hardly with much pleasure at seeing poor people evicted. In fact eviction saved lives, mavbe as many as fifty because buildings fell down in 1970 and 1972 Tazieff indeed supported a motion on 18 March 1970 which excluded the possibility of people reinhabiting old crumbling houses.

Very briefly, my involvement was this. I first reported the inversion of the Phleorean brady-seism to the authorities on 12 February 1970 , mentioning a ground upheaval of about $80 \mathrm{~cm}$ in little more than a year. I warned of the possibility of seismic phenomena and that even the continuation of the brady-seism might unsettle the buildings in the area. At the first shock (1 March 1970) a decree evacuating tottering buildings was issued, as a precaution. 650 shocks were recorded up to 16 November 1970. six felt in Pozzuoli itself at up to IV on the Mercalli scale. Three died in November from falling masonry and rocks. In my letter of 12 Fcbruary $I$ had foreseen a seismic, not an erubtive phenomenon.

For the sake of brevity I have only refuted a part of Tazieff's gratuitous statements: it would be possible, quoting published papers to amass much more scientific criticism. Tazieff states arbitrary conclusions in order to give value to the serious charge of a supposed participation in a "construction operation". He gives no direct proof, nor does any exist, while the indirect ones he reports are wrong or deliberately altered. Therefore all of his statements are nothing but products of fancy.

GiUSEPPE IMBò

Instituto di Geologia e Geofisica dell Universitì degli Studi,

Naples, Italy. 